\title{
Iceland on the periphery of the Scandinavian-design movement
}

Design and industry were literally unknown factors in Iceland until the inter-war years. This paper examines furniture as functional objects / artefacts in order to establish in what way this island territory, positioned on the Nordic periphery, was a part of the more centric Scandinavian-design movement during 1950-1970. Based on recent research of archival and visual resources and local furniture collections the paper looks at diverse roles acted out by the Home Industries Movement, local furniture manufacturers, craftsmen and a growing number of urban consumers along with a new profession of architects and furniture designers. It can be argued, in the case of Iceland, that furniture became a material novelty, as well as a leading carrier of memory for design in the early 2oth-century rather than the inherent tradition of textiles, carving and metalsmithing, so distinctive of the peasant society. On the other hand Scandinavian design became the most prominent force in the post-war period (1950-1970) and important model in furniture manufacturing during a period of flourishing furniture trade and production where authorship often became an issue. Concluding, in the case of Iceland, that peripheral territories tend to turn to regional - in this event Nordic - rather than global centers as models for local design.

keywords furniture manufacture, design history, Iceland, scandinavian design, local regional

\section{Introduction}

As important objects for the home, furniture mediate local or national tradition, transgress accepted rules in different ways in terms of technique and materials and reflect social and economic transformation in society. Firstly, this paper outlines the ground-breaking initiatives of designing furniture for rural and urban areas in Iceland in the period between the wars-and secondly how local craftsmen accepted non-traditional materials such as plywood and tubular steel at an early stage of modernism. The main focus, however, is on post-1945 furniture manufacturing and design efforts where for almost two decades (1950-1970) the phenomenon 'Scandinavian design' became a typical style and a common model for local manufacturers and designers.' The production sometimes bordered on plagiarism and thus authorship often became an issue - either copied from local design or from regional (Nordic) centers. Case studies of furniture craft manufacturing reveal that consumers favoured modern design for domestic interiors, and professional furniture craftsmen/designers and mechanics alike became important actors in transgressing 
theme 2

memory strand 1

design histories: tradition, transgression and transformations

tradition, welcoming new materials such as tubular steel, various metals and plastics for furniture.

\section{Early furniture design efforts}

Furniture was a rare commodity for the majority of the population of this peasant society throughout the centuries, only available as imports for the more affluent and powerful. Urbanization started gradually at the beginning of the zoth century. The progress in architecture and design is well exemplified in housing reforms. First, timber replaced turf and stone and by the 1930 s the modern construction material, concrete, had become the dominant material in urban as well as rural housing.

The housing reforms called for appropriate furniture. The first furniture design competition was initiated in 1927 by a leader of the Home Industries Movement with a strong focus on tradition and national identity - calling for a set of drawings of "Icelandic furniture" suitable for a living room in rural areas: a table, a bench, two chairs, cupboard and a bed. What was "Icelandic", however, was an undefined point of view-but the winning entry was made of solid wood (pine or birch) with decorative elements in the form of carving (Bjarnadóttir 1927: 39-40).

In contrast, more modernistic ideas of using non-traditional materials such as plywood and chromed tubular steel for furniture were introduced by blacksmiths and furniture craftsmen that had studied in Berlin and Frankfurt in the mid 1920s. The first tubular-steel furniture workshop started in 1933, soon manufacturing various types of furniture, mostly based on foreign models. ${ }^{2}$ Right from the outset this more avant-garde furniture was well received, but primarily for use in public spaces. Only the hard-core modernist used tubular steel furniture for domestic space, often adding handvowen traditionally patterned upholstery of Icelandic wool (Árnadóttir 2011: 122-128)

Figure 1. Tubular steel furniture, Stálhúsgögn Ltd, 1933-1952, (C) Museum of Design and Applied Art, A.M. Sigurjónsdóttir, photographer.

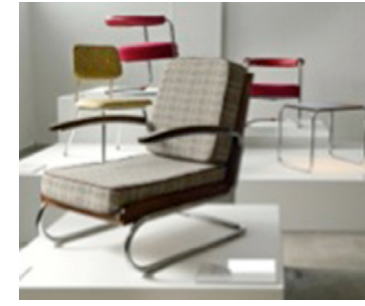

Rural housing reform continued in the 1930 s and another design competition was held in 1939, with similar intention (as in 1927) — that is ,to furnish a living room in rural areas". The outcome was different this time and more in tune with Nordic functionalism (Árnadóttir 2011: 104-110). Sadly neither competition was successful - in fact both of them failed in terms of output - very few proposals were submitted, necessary publicity was lacking and consequently very limited production followed. The 1939 event, however, is of importance since the three winning proposals, submitted by German and Danish educated furniture designers, all pointed towards new "modern ideas without any reference to copying styles or referring to tradition, national or furniture being "Icelandic" "(Árnadóttir 2011: 107). 


\section{Towards Scandinavian design and beyond}

Furniture manufacturing and design changed considerably in the post-war period. The 'modern movement' in architecture and design had entered its second phase - a phase that Banham has defined as "the second technical revolution" (Banham 1960: 9-12). Throughout Europe housing reforms became an important social priority during reconstruction and a demand for low-cost furniture increased as new materials and techniques were developed. All over Europe there was "a powerful desire to start anew" as Paul Betts and David Crowley have pointed out. The importance of the home and housing became:

"the centre of social policy in every European country after the war, despite extremely divergent experiences of material decimation, housing shortages, social dislocation and refugee crises" (Betts \& Crowley 2005: 215).

Iceland was no exception, but was neither faced by refugee crisis nor directly affected by the war in a catastrophic way. Declaring independence from Denmark in 1944, a fast urbanization followed over a short period of time, resulting in acute housing shortages in urban areas. Numerous new housing developments were started (for example in Reykjavík) at the beginning of the 1950 s and more than ever, objects for the home became of central interest. The demand for furniture in the "new modern style" was great, urban consumers were generally biased towards modern design and welcomed the machine technology in the service of design in the form of new materials for furniture (Árnadóttir 2011: 175-176).

The pre-war voices of the housing reformists calling for furniture in rural areas had completely quiteted down. Now the call was for a new style, mostly based on Nordic functionalism, simple in form and suitable for urban or rural homes alike. First to introduce this style to the public at an exhibition in Reykjavík in 1946 was the Swedish Society for Art and Crafts [Svenska Slöjdforeningen] under the directorship of Ake Stavenow who himself visited Iceland on that occasion (Stavenow 1946: 220-222). Six years later, on the other hand, the first 'modern furniture' production in the Scandinavian style made by local manufacturers appeared at a nation-wide industrial exhibition in Reykjavík in 1952 (Sjónlist 2008: 77). From then on the furniture trade flourished as never before for the next two decades. Furniture craft became a viable profession, many new workshops were established in the two main urban areas and the number of tradesmen in the furniture craft almost doubled in number in the period 1950 to 19703. The majority, however, were small machine-assisted craft workshops working exclusively in wood and only three of them had capacity for full-blown industry, employing between 50-100 people (Árnadóttir 2011: 216-222).

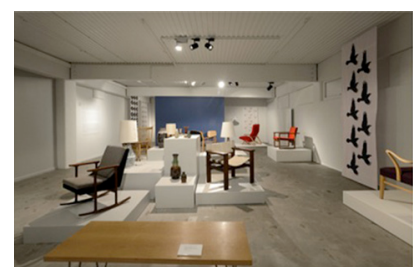

Figure 2. Furniture, 1950-1970, Chance Encounters Towards Modernity in Icelandic Design (June 2013 January 2014), (c) Museum of Design and Applied Art, A. M. Sigurjónsdóttir, photographer.

\footnotetext{
${ }^{3}$ According to Hagskinna, Icelandic historical statistics, Reykjvík, 1997, the number of cabinetmakers and joiners increased from 789 in 1950 to 1446 in 1970 (Árnadóttir 2011: 218).
} 
The local furniture production met the demands of the consumers during this period mainly because of government regulated economy with tariff barriers and restrictions on imports, first imposed in the 1930 lasting until 1959. Then they were gradually eased in steps until Iceland joined EFTA- the European Free Trade Association in 1970. During this period (1959-1970) of adjustment to free trading some important furniture design initiatives can be identified.

\section{For everyone's taste}

Manufacturing low-cost furniture in wood in any volume did not start until after the second world war, when a small carpentry workshop, Vídir (est. 1930), moved into larger premises in Reykjavík in 1946 and expanded quickly. By 1957 employing 75 and close to 100 at the height of its production in the 1960s, then being the largest in the country. The main intention was to make "furniture for everyone 's taste", at affordable prices, rather than develop new types of design. The company was run by a blind carpenter turned businessman who rarely turned to local professional designers until after 1970 when free trading approached - to him consumers' consent was essential for business. Gradually the demand for a light, modern style in oiled teak or light colored woods overshadowed the production of dark, polished, traditional sets of furniture the company claimed to be their "best quality". On the other hand, the low-cost modern furniture manufactured by Viðir Ltd was often based on foreign or local models whose authorship was difficult to trace.

Conversely the other two, often competing, carpentry workshops of Kristján Siggeirsson Ltd in Reykjavík and Valbjörk Ltd in Akureyri were leading in manufacturing exclusively in the modern style. Both companies were run by craftsmen educated as furniture designers in Switzerland, Sweden and Denmark, strongly favouring Scandinavian design. During the 1960 s their production was more focused on catering to the private space. Predominantly middle-class consumers welcomed a great variety of furniture and modular components in teak, oak and rosewood intended for the "model interior" they hoped for. And in tune with Baudrillard's Le système des objets, furniture of the 1960 s was very distinct from the past-now modular seating and storage components gave the homes an atmosphere of both functionality and openness. The old more massive polished furniture had been abandoned "in favour of an extremely free interplay of functions" (Baudrillard 1968: 19).

New materials and techniques seemed to appeal as well to "everyone's taste". The management of Vídir Ltd., for example, took initiatives at the beginning of the 196os, when import restrictions ceased, to secure a license from a Norwegian firm Plastmøbler $\mathrm{A} / \mathrm{S}$ in Kristiansand to produce shells made of reinforced plastic (polyurethane-foam) for upholstered chairs and sofas. The models were designed by the Norwegian designer Henry W. Klein (Árnadóttir 2011: 240-241;Halén 1999:48-51). For almost a decade the manufacturing of low-cost "plastic furniture" of this type continued to be important for the company and one of their best selling products in the 1960 (Briem 1968. 224).

\section{Transgressing the traditional}

Manufacturing of chromed tubular steel furniture continued after 1945 - and from the mid 1950 s the role of blacksmiths, mechanics and artists in designing for furniture made of metal counterbalanced a growing profession of mostly Danish educated furniture designers with a strong background in traditional furniture crafts. In some instances this created both friction as well as innovation. During the period of import restrictions and regulations there was a constant battle for materials such as wood. But metal rods were 
plentiful in the large metal and mechanical workshops serving the industries in Iceland.

Collaboration between furniture designers and the above mentioned mechanically minded 'actors' produced some noteworthy design efforts. Experiments went on in large mechanical workshop like Sindri Ltd where considerable amount of furniture using iron rods, plywood and plastic shells were produced for the domestic market. But also in small carpentry workshops where limited output and prototypes of chairs and tables made of iron rods and colorful plastic strings were a delight. Indeed the local avant-garde efforts reflected popular foreign, more centric, models but also indicated local innovation and strength in craftmanship in the use of different materials making them 'distinctive' - and a viable contribution to a more centric design.

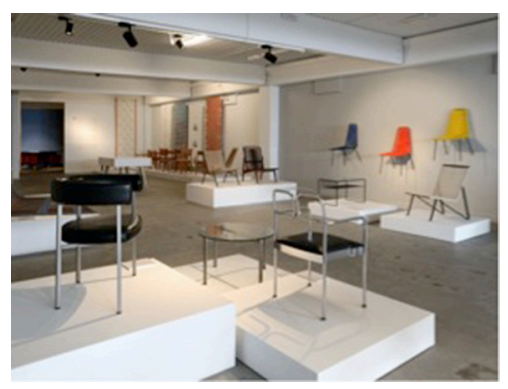

Figure 3 . Metal furniture, 1950-1970, Chance EncountersTowards Modernity in Icelandic Design (June 2013 - January 2014), (CMuseum of Design and Applied Art, A. M. Sigurjónsdóttir, photographer.

\section{Conclusion}

Unlike the neighbouring countries Iceland did not have a long tradition of furniture crafts. In the early 2oth century furniture gradually became an important commodity following housing reforms and the arrival of the Modern Movement in architecture. It can be argued that since tradition was lacking the reception of new materials and techniques for furniture was favourable. In small markets and marginal territories as in the case of furniture production in Iceland in the post-1945 period, the manufacturers, craftsmen and designers alike looked for Scandinavian models for urban consumers' consent. Smaller workshops tended to copy from local design / designers and larger manufacturers looked for regional models, turning to Scandinavian design. During the period miniscule peripheral territories and markets such as Iceland used local and regional rather than global centers as models for design. Iceland in terms of design was thus situated on the periphery of the Scandinavian design-movement.

\section{References}

Árnadóttir, A. S. (2011) Nútímaheimilið i mótun-fagurbœtur, funksjónalismi og norroen áhrif á íslenska hönnun 1900-1970 [The modern domestic interior-aesthetic reform, functionalism and Nordic influence on Icelandic design 1900-1970], Ph.D. thesis University of Iceland. Reykjavík: Háskólaútgáfan.

Banham, R. (1960;2002) Theory and design in the first machine age. Oxford: Architectural Press.

Baudrillard, J. (1968; 2005) System of objects. London: Verso.

Betts, P. \& Crowley, D. (2005) "Introduction", Journal of Contemporary History, vol. 40, no. 2, pp. 213-236, Available Sage Journals: http://jch.sagepub.com/content/40/2/213. full.pdf+html 
Bjarnadóttir, H. (1927) "Verðlaunasamkeppni um uppdrætti að íslenskum húsgögnum" [Competition for design of Icelandic furniture], Hlín, vol. 18, pp. 37-41.

Briem, S. (1968) "Hann sér með fingurgómunum" [His fingertips are his eyes], Myndbrot: Í svipmyndum 2. Reykjavík: Prentsmiðjan Leiftur, pp.223-227.

Halén, V. (1999) "The patent that revolutionised the furniture industry the world over-. Scandinavian Journal of Design History vol. 9, pp. 41-55.

Sjónlist [Visual arts]. Exhibition catalogue (2008) "Hjalti Geir Kristjánsson interviewed by Arndís S. Árnadóttir", pp. 76-84.

Stavenow, A. (1946) "Kontakt med Island", Form, vol. 42, no. 10, pp. 220-222.

Woodham, J. (2005) "Local, national and global: redrawing the design historical map", Journal of Design History, vol. 18, no. 3, pp. 257-265. 